cemoti $\begin{aligned} & \text { Cahiers d'études sur la Méditerranée } \\ & \text { orientale et le monde turco-iranien }\end{aligned}$

$38 \mid 2006$

Islam au Caucase

\title{
Être jeune militant nationaliste azéri en Iran
}

Gilles RIAUX

\section{OpenEdition}

Journals

Édition électronique

URL : http://journals.openedition.org/cemoti/1550

DOI : $10.4000 /$ cemoti. 1550

ISSN : $1777-5396$

Éditeur

AFEMOTI

Édition imprimée

Date de publication : 20 février 2006

ISSN : 0764-9878

Référence électronique

Gilles RIAUX, «Être jeune militant nationaliste azéri en Iran », Cahiers d'études sur la Méditerranée orientale et le monde turco-iranien [En ligne], 38 | 2006, mis en ligne le 13 février 2006, consulté le 08 septembre 2020. URL : http://journals.openedition.org/cemoti/1550 ; DOI : https://doi.org/10.4000/ cemoti. 1550

Ce document a été généré automatiquement le 8 septembre 2020.

Tous droits réservés 


\title{
Être jeune militant nationaliste azéri en Iran
}

\author{
Gilles RIAUX
}

\section{RÉSUMÉS}

Cet article analyse l'engagement nationaliste des jeunes Azéris d'Iran à travers trois angles complémentaires. D'abord, une approche en terme d'espaces de mobilisation explique comment les futurs militants accèdent à un discours d'opposition au régime islamiste. Ensuite, l'analyse se déplace vers les logiques de l'engagement militant, que ce soit en terme de déterminants ou de rétributions. Sortir d'une approche macrosociologique et s'intéresser à l'expérience vécue permettent de mettre en évidence l'importance des dimensions affective et identitaire. Enfin, la dimension cognitive de l'engagement est étudiée en questionnant les concepts d'habitus et d'articulation des univers de sens. Ainsi apparaissent les contours d'une jeunesse iranienne polysémique qui a en commun des préoccupations et des difficultés, mais les exprime de manière différenciée. 